Józef Szubert, Stawomir Szubert, Wojciech Wieczorek, Alicja Szymańska-Paszczuk

\title{
Własna, nieinwazyjna metoda wyznaczania pojemności minutowej (CO) i objętości wyrzutowej (SV) serca dziewcząt i chłopców w wieku 7-9 lat podczas wysiłku fizycznego
}

\section{Our own, non-invasive method of measuring the cardiac output (CO) and stroke volume (SV) in children aged 7-9 during physical exercise}

Introduction: Cardiac output (CO) determines the cardiovascular system's function and undergoes fluctuations in various physiological and pathological states. All of the currently available $\mathrm{CO}$ monitoring methods have their limitations, which is the reason we keep looking for new, possibly simple, cost-effective and safe, but still reliable methods.

Materials and methods: Based on both our own and global empiric data and laws of thermodynamics and fluid dynamics, we developed a new, non-invasive and safe method of measuring cardiac output and the stroke volume (SV). The aforementioned method allows us to measure both CO and $\mathrm{SV}$ in children undergoing various relative workload exercise.

Results: CO and SV values obtained by the author's method do not differ significantly from the values obtained by other researchers using different methods.

Conclusions: The developed method is non-invasive, simple, cost-effective, reliable and poses no risk for the examined person's life or health. It can be a viable alternative to the currently used methods. 


\section{Wprowadzenie}

Wysiłek fizyczny człowieka wymaga skoordynowanych działań układu nerwowego, krążenia, oddechowego oraz wydzielania wewnętrznego w celu pokrycia zwiększonego zapotrzebowania energetycznego pracujących mięśni. Reakcja poszczególnych układów musi być zintegrowana z oddychaniem komórkowym i czynnością pozostałych układów, np. termoregulacji, w celu utrzymania homeostazy (Wilmore i in., 2008, Kozłowski, Nazar, 1999, Powers, Howley, 2009, Mędraś, 2010, Matthews, 2000).

Układ krążenia w ścisłej współpracy z układem oddechowym odgrywa istotną rolę $w$ dostarczaniu tlenu do pracujących mięśni w ilości pozwalającej na tlenowe procesy metaboliczne, w usuwaniu dwutlenku z mięśni, w usuwaniu ciepła powstałego w procesach metabolicznych, w transporcie hormonów biorących udział w regulacji różnych układów podczas wysiłku (Górski, 2008; Fox, 2008, Guyton, 1963, Keleman, 1977).

Zasadnicze znaczenie w reakcji układu krążenia na wysiłek ma zwiększenie przepływu krwi przez mięśnie, płuca i skórę. Jest to związane ze zwiększeniem ilości krwi przepompowywanej w jednostce czasu przez serce i ze zmianą dystrybucji przepływu krwi przez różne narządy. Ilość krwi wyrzucana w ciągu jednej minuty do aorty odpowiada pojemności minutowej serca (rzutowi minutowemu serca, CO). W warunkach prawidłowych w spoczynku pojemność minutowa lewej i prawej komory jest taka sama. Ponieważ wartość ta zależy od wzrostu i masy ciała badanego, rzut minutowy określany jest w stosunku do powierzchni ciała $A_{D}\left[m^{2}\right]$ i nazywany wskaźnikiem sercowym. W spoczynku prawidłowy wskaźnik sercowy wynosi 2,4-4,0 L/min $\cdot \mathrm{m}^{2}$; średnio $3,1 \mathrm{~L} / \mathrm{min} \cdot \mathrm{m}^{2}$. Objętość wyrzutowa serca (SV) określa ilość krwi jaką jedna komora tłoczy do tętnic podczas jednego skurczu (Keleman, 1977, Klabunde, 2011, Jaskólski, Jaskólska, 2006, Astrand i in., 2003, Guyton, Hall, 2005).

Podczas wysiłków z małym obciążeniem zwiększenie pojemności minutowej serca uwarunkowane jest zwiększeniem objętości wyrzutowej (SV) i częstotliwości pracy serca (HR). Podczas wysiłków o umiarkowanym i dużym obciążeniu pojemność minutowa serca zwiększa się właściwie tylko dzięki zwiększeniu częstotliwości pracy serca (Wilmore i in., 2008, Kozłowski, Nazar, 1999, Powers, Howley, 2009, Fox, 2008).

Przepływ krwi w czasie wysiłku ulega redystrybucji. W spoczynku około $80 \%$ pojemności minutowej płynie do narządów wewnętrznych - wątroby, nerek, mózgu i serca. Mięśnie otrzymują około $15 \%$ krwi krążącej. Przepływ mięśniowy podczas maksymalnego wysiłku u ludzi zdrowych wzrasta do 75-80\% pojemności minutowej serca. Podczas wysiłku rośnie ekstrakcja tlenu w tkankach i różnica tętniczo-żylna zawartości tlenu (AVD) może wzrosnąć 3-4 krotnie podczas maksymalnego wysiłku (Wilmore i in., 2008, Kozłowski, Nazar, 1999, Keleman, 1977, Klabunde, 2011).

Wśród wszystkich parametrów hemodynamicznych najważniejsze pod względem klinicznym i w sporcie są: pojemność minutowa serca (CO), objętość 
wyrzutowa (SV), częstość pracy serca (HR) opór naczyń obwodowych (SVR) (Orłowski, 1988, Chlebus, Januszewicz, 1984, Rużyło, Purzycki, 1984, Trafidło i in. 2010).

Pojemność minutowa serca (rzut serca, CO) jest jednym z najczęściej używanych w praktyce klinicznej parametrów hemodynamicznych. Monitorowanie pojemności minutowej serca ma nieocenione znaczenie terapeutyczne i prognostyczne, zwłaszcza u pacjentów krytycznie chorych (Orłowski, 1988, Chlebus, Januszewicz, 1984, Rużyłło, Purzycki, 1984, Trafidło i in. 2010).

Ocenę parametrów hemodynamicznych przeprowadza się z wykorzystaniem metod o dużej i ograniczonej inwazyjności oraz nieinwazyjnych.

\section{Metody inwazyjne}

1. Bezpośrednia metoda Ficka, która pierwszy raz zaprezentowana została przez Adolfa Ficka. Pomiar rzutu minutowego bezpośrednio metodą Ficka zastosował u człowieka po raz pierwszy w 1929 roku Forssman, który wykonał doświadczenie na sobie samym, a wkrótce potem (1930 roku) powtórzył to badanie Klein. Metoda ta wymaga cewnikowania serca (Guyton, 1963, Best, Taylor, 1971).

Od 1971 roku prawa komora serca cewnikowana jest zwykle z zastosowaniem cewnika Swan-Ganza, z pływającym balonikiem, który po napełnieniu przemieszcza się z prądem krwi do gałęzi pnia tętnicy płucnej. W bezpośredniej metodzie Ficka mierzy się całkowitą konsumpcję tlenu w jednostce czasu i prężność tlenu we krwi tętniczej i żylnej. Wartość rzutu serca wylicza się dzieląc całkowite zużycie tlenu przez tlenową różnicę tętniczo-żylną.

Bezpośrednia metoda Ficka stanowi podstawę wielu technik pomiaru rzutu serca i służy do weryfikacji innych metod. Aktualnie bezpośrednią metodę Ficka wykorzystuje się przede wszystkim do celów badawczych (Guyton, 1963, Orłowski, 1988, Chlebus, Januszewicz, 1984, Rużyłło, Purzycki, 1984, Best, Taylor, 1971, Guzik i in., 2002, Branderburg, 1987, Pepine, 1997, De Maria, Raisingham, 2000, Jarvis i in., 2007, Peyton, Thompson, 2004).

2. Pośrednia metoda Ficka. W odróżnieniu od metody bezpośredniej, w metodzie tej nie mierzy się całkowitej konsumpcji tlenu. Wykorzystuje się tu pomiar pulsu oksymetryczny wysycenia tlenem krwi tętniczej, określając równolegle zawartość hemoglobiny we krwi oraz powierzchnię ciała osoby badanej. Technika ta jest mniej uciążliwa od metody bezpośredniej (Guzik i in., 2002, Branderburg, 1987, Pepine, 1997, De Maria, Raisingham, 2000 i in., 1994).

3. Metody rozcieńczeń wskaźnika opierają się na teoretycznych podstawach opracowanych przez Ficka. W technikach tych zamiast określania zużycia i stężeń tlenu wykorzystuje się pomiar rozcieńczenia we krwi nietoksycznego barwnika lub zmiany temperatury wstrzykniętego płynu lub przepływającej krwi. Metoda ta została opisana przez Stewarda w 1897 roku, a następnie rozwinięta przez Hamiltona i wsp.

a. Metoda rozcieńczenia barwnika. Do pnia tętnicy płucnej wstrzykuje się określoną ilość barwnika, np. chlorku litu lub zieleni indocyjaninowej, ze stałą 
prędkością. W pobranych próbkach krwi mierzy się densytometrycznie zmiany stężenia barwnika w czasie i wyznacza się krzywą stężeń. Rzut serca wylicza się z ilorazu ilości wstrzykniętego barwnika i pola powierzchni pod uzyskaną krzywą zmian stężenia wstrzykniętego barwnika. Metoda ta rzadko znajduje zastosowanie w praktyce klinicznej (Guyton, 1963, Orłowski, 1988, Chlebus, Januszewicz, 1984, Rużyłło, Purzycki, 1984, Best, Taylor, 1971, Guzik i in., 2002, Branderburg, 1987, Pepine, 1997, De Maria, Raisingham, 2000).

b. Metoda termodylucji. W technice tej zamiast barwnika stosuje się schłodzony roztwór soli fizjologicznej lub 5\% glukozy. Termistor umieszczony na końcu cewnika pływającego w tętnicy płucnej określa temperaturę wewnątrz ciała oraz zmianę temperatury otaczającej krwi po wstrzyknięciu schłodzonego płynu. W ten sposób uzyskuje się krzywą zmiany temperatury w czasie, którą następnie wykorzystuje się - podobnie jak w metodzie barwnikowej - do wyliczenia rzutu serca. Pomiar wykonuje się od trzech do pięciu razy, a uzyskane wyniki uśrednia. Termodylucja jest aktualnie najczęściej używaną metodą do klinicznej oceny rzutu serca. Obarczona jest błędem rzędu 15-20\% i nie nadaje się do ciągłego monitorowania rzutu serca (Orłowski, 1988, Chlebus, Januszewicz, 1984, Rużyłło, Purzycki, 1984, Best, Taylor, 1971, Guzik i in., 2002, Branderburg, 1987, Pepine, 1997, Jarvis i in., 2007, Peyton, Thompson, 2004, Hirschl i in., 2000, Wiesenack i in., 2001, Gödje i in., 2002, Mayer i in., 2007, Ganz i in. 1971).

c. Metoda CCO - ciągłego pomiaru rzutu serca. Metoda jest podobna do termodylucji. Cewnik umiejscowiony w prawym sercu jest zaopatrzony w niewielką grzałkę, która okresowo podgrzewa otaczającą krew, a termistor zlokalizowany na końcu cewnika pływającego w tętnicy płucnej mierzy zmiany temperatury przepływającej krwi (Orłowski, 1988, Chlebus, Januszewicz, 1984, Rużyłł, Purzycki, 1984, Guzik i in., 2002, Della Rocca i in., 2002, Kurita i in., 1997).

4. Cewnikowanie lewego serca i wentrykulografia. Wentrykulografia jest metodą radiologiczną, w trakcie której przez cewnik podaje się środek kontrastowy do lewej komory serca. Z projekcji jedno- lub dwupłaszczyznowych ocenia się późnoskurczową i późnorozkurczową objętość lewej komory, a następnie oblicza się objętość wyrzutową i rzut serca. Wentrykulografia nie pozwala na ciągłe monitorowanie parametrów hemodynamicznych (Guyton, 1963, Orłowski, 1988, Rużyło, Purzycki, 1984, Guzik i in., 2002, Branderburg, 1987, Pepine, 1997).

Do metod o ograniczonej inwazyjności należą następujące:

1. Metody radiologiczne, w których wykorzystuje się środki kontrastowe podawane dożylnie, które po dotarciu z krwią do lewej komory pozwalają ocenić jej zarys zarówno w okresie skurczu jak i rozkurczu (Guyton, 1963, Orłowski, 1988, Chlebus, Januszewicz, 1984, Rużyłło, Purzycki, 1984, Best, Taylor, 1971, Guzik i in., 2002, Braunwald, 1998):

a. Cyfrowa angiografia subtrakcyjna (DSA).

b. Tomografia komputerowa o wysokiej szybkości skanowania (cime - CT).

2. Angiografia radiologiczna (Guyton, 1963, Taylor, 1971, Guzik i in., 2002, Braunwald, 1998). 


\section{Metody nieinwazyjne}

1. Rezonans magnetyczny (Guzik, i in., 2002, Branderburg, 1987).

2. Echokardiografia (Orłowski, 1988, Chlebus, Januszewicz, 1984, Rużyłło, Purzycki, 1984, Guzik i in., 2002, Branderburg, 1987, Pepine, 1997, De Maria, Raisingham, 2000, Kucewicz i in., 2003, Bródka i in., 2010, Balik i in., 2004, Swanevelder, 2001, Benson, Cahalan, 1995, Darmon i in., 1994, Feinberg i in. 1995).

a. Echokardiografia dwuwymiarowa (2-D).

b. Echokardiografia dopplerowska. Echokardiografia z wykorzystaniem efektu Dopplera polega na pomiarze zmian prędkości przepływu strumienia krwi w aorcie.

c. Przezprzełykowa echokardiografia dopplerowska. W metodzie tej istnieje konieczność wprowadzenia do przełyku głowicy ultrasonograficznej. Dlatego metoda ta określana jest mianem pótinwazyjnej.

3. Metoda konturowa. Metoda ta umożliwia obliczanie wielkości rzutu serca na podstawie cyfrowej obróbki zapisu zmian fali ciśnienia mierzonej w tętnicach obwodowych. Metoda konturowa określa dynamikę i kształt ciągłych krzywych kreślonych przez tętnicze ciśnienie skurczowe i rozkurczowe (Guyton, 1963, Rużyłło, Purzycki, 1984, Best, Taylor, 1971, Guzik i in., 2002, Hirschl i in., 2000, Jansen i in., 1990, Sherwood i in., 1998, Strobeck, Silver, 2000, Wright, Gilbert, 2000, Raaijmaker i in., 1997, Wtorek, 2000).

4. Elektryczna bioimpedancja klatki piersiowej (TEB) (De Maria, Raisingham, 2000, Della Rocca i in., 2002, Strobeck, Silver, 2000, Wright, Gilbert, 2000, Raaijmakers i in., 1997). Metoda ta, określona również mianem kardiografii impedancyjnej, opiera się na bezpośrednim związku między przepływem krwi przez badaną część ciała a zmianą bioimpedancji (oporność żywych tkanek) w jej obrębie. Osocze krwi to najlepiej przewodząca prąd elektryczny tkanka w ustroju człowieka. Czerwone krwinki są elementami o znacznie gorszym przewodzeniu, wynikającym z większej oporności elektrycznej. Chwilowa zmiana ukierunkowania i ilości czerwonych krwinek, a także objętość krwi przepływającej przez naczynia determinują wielkość impedancji. Wzrostowi ilości krwi przepływającej przez aortę towarzyszy przejściowa poprawa przewodnictwa klatki piersiowej i spadek wartości bioimpedancji, zaś w chwili zmniejszenia ilości krwi w aorcie oporność elektryczna wzrasta.

5. Oznaczanie rzutu minutowego serca z użyciem obojętnego gazu obcego. Metoda ta oparta jest na zasadzie określanej jako zamknięty system oddychania obojętnym gazem. W metodzie tej wykorzystuje się zamknięty system z torbą oddechową, do której podaje się mieszaninę obojętnego dla organizmu, rozpuszczalnego we krwi gazu, np. podtlenku azotu $-\mathrm{N}_{2} \mathrm{O}$ lub acetylenu $-\mathrm{C}_{2} \mathrm{H}_{2}$. Odpowiednie urządzenie dokonuje pomiaru krzywej stężenia tego gazu oraz wylicza współczynnik oczyszczenia, który jest proporcjonalny do rzutu serca. Metoda ta jest nieinwazyjna, pozwala na ciągły pomiar parametrów hemodynamicznych (Best, Taylor, 1971, Guzik i in., 2002, Jarvis i in., 2007, Nilsson i in., 2001, Laszlo, 2004, Liu i in., 1997, Nielsen i in., 1990, Olszowska i in., 2004, Zeidifard, Davis, 
1978). Ciągle poszukuje się nowych sposobów pozwalających w sposób prosty, bezpieczny i wiarygodny ocenić pojemność minutową serca $(\mathrm{CO})$ i inne parametry hemodynamiczne.

Celem autorów artykułu jest opracowanie własnej, nieinwazyjnej metody wyznaczania pojemności minutowej (CO) oraz objętości wyrzutowej (SV) serca podczas wysiłków fizycznych, które będą wiarygodne oraz bezpieczne dla zdrowia i życia osób badanych.

\section{Materiał i metody}

Na podstawie własnych i pochodzących z badań innych autorów danych empirycznych, prawa wymiany ciepła (Staniszewski, 1980; Hobler, 1979), mechaniki płynów (Landau, 1958, Bukowski, 1976) oraz zasady modelowania i symulacji komputerowej układów biologicznych (Szubert, 1981, Keener, Sneyd, 1998), opracowano model regulacji temperatury wraz z elementami układu krążenia i oddychania organizmu człowieka (Szubert, 1980). Dotychczas w literaturze nie opisano podobnego modelu. Wykorzystanie modelu pozwoliło opracować własną, nieinwazyjną, wiarygodną i bezpieczną metodę wyznaczania pojemności minutowej serca (CO) i objętości wyrzutowej serca (SV) u dzieci w wieku 7-9 lat. W metodzie tej wyznacza się CO i SV w funkcji względnego obciążenia wysiłkiem fizycznym $\left(\% \mathrm{Vo}_{2}\right.$ max $)$, powierzchni ciała człowieka $\left(A_{D}\right)$, maksymalnego poboru tlenu ( $\mathrm{Vo}_{2}$ max) oraz częstości pracy serca (HR).

Dla dziewcząt w wieku od 7 do 9 lat CO i SV można wyznaczyć ze wzorów:

$$
\mathrm{CO}=0,564 \mathrm{Vo}_{2} \max \cdot \mathrm{A}_{\mathrm{D}}^{0,421}\left(\% \mathrm{Vo}_{2} \max \right)^{0,579}[\mathrm{~L} / \mathrm{min}]
$$

oraz

$$
\mathrm{SV}=\frac{\mathrm{CO}}{\mathrm{HR}}[\mathrm{mL}]
$$

gdzie:

CO - pojemność minutowa serca (rzut minutowy serca),

SV - objętość wyrzutowa serca,

$\mathrm{Vo}_{2}$ max - maksymalny pobór tlenu, wieka,

$A_{D}=0,20247 \mathrm{~m}^{0,435} \mathrm{H}^{0,725}\left[\mathrm{~m}^{2}\right]$ (równanie Du Bois) - powierzchnia ciała czło-

$\mathrm{m}$ - masa ciała wyrażona w kilogramach,

$\mathrm{H}$ - wzrost człowieka wyrażony w metrach,

$\% \mathrm{Vo}_{2}$ max - względne obciążenie wysiłkiem fizycznym, HR [1/min] - częstość pracy serca.

Dla chłopców w wieku od 7 do 9 lat Co i SV można wyznaczyć ze wzorów:

$$
\mathrm{CO}=0,5157 \mathrm{Vo}_{2} \max \cdot \mathrm{A}_{\mathrm{D}}^{0,421}\left(\% \mathrm{Vo}_{2} \max \right)^{0,579}[\mathrm{~L} / \mathrm{min}]
$$


oraz

$$
\mathrm{SV}=\frac{\mathrm{CO}}{\mathrm{HR}}[\mathrm{mL}],
$$

gdzie: objaśnienia jak wyżej.

Ocenę wiarygodności wyników CO i SV otrzymanych za pomocą własnych metod, dokonano przez porównanie ich z wynikami badań wykonanych u tych samych dziewcząt i chłopców, innymi metodami, przez innych badaczy: Turleya i Wilmore (Turley, Wilmore, 1997). Aby takie porównanie wyników mogło być dokonane, autorzy obecnej pracy znając względne obciążenie wysiłkiem fizycznym (\% $\mathrm{Vo}_{2}$ max), powierzchnię ciała $\left(\mathrm{A}_{\mathrm{D}}\right)$, maksymalny pobór tlenu $\left(\mathrm{Vo}_{2} \mathrm{max}\right.$ ) oraz częstość pracy serca (HR) badanych dziewcząt i chłopców, które zostały wykonane przez Turleya i Wilmore, własną metodą wyznaczyli CO i SV dla tych samych dziewcząt i chłopców. Taki sposób weryfikacji zapewnia pełen obiektywizm.

\section{Wyniki badań}

W swojej pracy Turley i Wilmore 1997 badali reakcje sercowo-naczyniowe u dzieci w wieku od 7 do 9 lat. Grupa 12 dziewcząt i grupa 12 chłopców wykonywały wysiłek fizyczny przy trzech różnych względnych obciążeniach na ergometrze rowerowym i na bieżni ruchomej. Dane morfometryczne dziewcząt przedstawiono w tabeli 1, natomiast chłopców w tabeli 4. Parametry fizjologiczne wyznaczone przez Turleya i Wilmore to między innymi CO i SV. Znając względne obciążenie wysiłkiem fizycznym (\% $\left.\% \mathrm{~V}_{2} \max \right)$, powierzchnię ciała $\left(\mathrm{A}_{\mathrm{D}}\right)$, maksymalny pobór tlenu ( $\mathrm{Vo}_{2}$ max) i częstość pracy serca (HR), dziewcząt i chłopców, które zostały wyznaczone przez Turleya i Wilmore, autorzy niniejszej pracy dla tych samych dziewcząt i chłopców własną metodą wyznaczył CO i SV. Wyniki przeprowadzonych badań zostały przedstawione: dla dziewcząt w tabelach 2 i 3 oraz na rycinach $1-4$, natomiast dla chłopców w tabelach 5 i 6 oraz na rycinach 5-8.

Tabela 1. Dane morfometryczne dziewcząt w wieku od 7 do 9 lat badanych przez Turleya i Wilmore

\begin{tabular}{|c|c|c|c|c|c|c|}
\hline $\begin{array}{c}\text { Liczba } \\
\text { osób }\end{array}$ & $\begin{array}{c}\text { Wiek } \\
{\left[\begin{array}{c}\text { w latach] } \\
\text { średnie }\end{array}\right.}\end{array}$ & $\begin{array}{c}\mathbf{m}[\mathrm{kg}] \\
\text { średnie }\end{array}$ & $\begin{array}{c}\mathbf{H}[\mathrm{m}] \\
\text { średnie }\end{array}$ & $\begin{array}{c}\mathbf{A}_{\mathrm{D}}\left[\mathrm{m}^{2}\right] \\
\text { średnie }\end{array}$ & $\begin{array}{c}\mathrm{Vo}_{2} \mathrm{max}^{2} \\
{[\mathrm{~L} / \mathrm{min}]}\end{array}$ & $\begin{array}{c}\mathrm{Vo}_{2} \mathrm{max}^{3} \\
{[\mathrm{~L} / \mathrm{min}]}\end{array}$ \\
\hline 12 & 8,8 & 28,5 & 1,33 & 1,02 & $1,33 \pm 0,26$ & $1,51 \pm 0,23$ \\
\hline
\end{tabular}

$\mathrm{m}$ - masa ciała,

$\mathrm{H}$ - wysokość ciała,

$A_{D}$ - powierzchnia ciała,

$\mathrm{Vo}_{2} \max ^{2}-$ maksymalne pochłanianie tlenu na ergometrze rowerowym,

$\mathrm{Vo}_{2} \mathrm{max}^{3}$ - maksymalne pochłanianie tlenu na bieżni ruchomej.

Źródło: Turley, Wilmore (1997). 
Tabela 2. Wartości pojemności minutowej i objętości wyrzutowej serca przy różnych względnych obciążeniach wysiłkiem fizycznym dziewcząt na ergometrze rowerowym, wyznaczone przez Turleya i Wilmore oraz własną metodą przez autorów pracy

\begin{tabular}{|c|c|c|c|c|c|c|c|c|c|}
\hline $\begin{array}{c}\mathrm{Vo}_{2} \\
\text { [L/min] } \\
\text { średnie }\end{array}$ & $\begin{array}{c}\mathrm{Vo}_{2} \max ^{2} \\
\text { [L/min] } \\
\text { średnie }\end{array}$ & $\begin{array}{c}\% \mathrm{Vo}_{2} \max ^{2} \\
\text { średnie }\end{array}$ & $\begin{array}{c}\mathrm{CO} \\
{[\mathrm{L} / \mathrm{min}]}\end{array}$ & $\begin{array}{c}\mathrm{CO}^{*} \\
{[\mathrm{~L} / \mathrm{min}]}\end{array}$ & $\begin{array}{c}\text { Różnica } \\
\text { procen- } \\
\text { towa }\end{array}$ & $\begin{array}{c}\text { HR } \\
{[1 / \mathrm{min}]}\end{array}$ & $\begin{array}{c}\text { SV } \\
{[\mathrm{mL}]}\end{array}$ & $\begin{array}{l}S^{\text {SV }} \\
{[\mathrm{mL}]}\end{array}$ & $\begin{array}{c}\text { Różnica } \\
\text { procen- } \\
\text { towa }\end{array}$ \\
\hline 0,51 & 1,33 & 38,35 & 6,6 & 6,3 & 4,55 & 118,9 & 55,5 & 53,0 & 4,50 \\
\hline 0,75 & 1,33 & 56,39 & 8,1 & 7,8 & 3,70 & 140,8 & 57,5 & 55,4 & 3,65 \\
\hline 0,98 & 1,33 & 73,68 & 9,1 & 9,2 & 1,09 & 159,7 & 57,0 & 57,6 & 1,04 \\
\hline
\end{tabular}

$\mathrm{Vo}_{2} \mathrm{max}^{2}$ - maksymalne pochłanianie tlenu na ergometrze rowerowym, $\% \mathrm{Vo}_{2} \max ^{2}$ - wartość względnego obciążenia wysiłkiem fizycznym. CO - pojemność minutowa serca wyznaczona przez Turleya i Wilmore, CO* - pojemność minutowa serca wyznaczona własną metodą przez autorów pracy, HR - częstość pracy serca,

SV - objętość wyrzutowa serca wyznaczona przez Turleya i Wilmore,

$\mathrm{SV}^{*}$ - objętość wyrzutowa serca wyznaczona własną metodą przez autorów pracy.

Źródło: Turley, Wilmore (1997); badania własne autorów.

Tabela 3. Wartości pojemności minutowej i objętości wyrzutowej serca przy różnych względnych obciążeniach wysiłkiem fizycznym dziewcząt na bieżni ruchomej, wyznaczone przez Turleya i Wilmore oraz własną metodą przez autorów pracy

\begin{tabular}{|c|c|c|c|c|c|c|c|c|c|}
\hline $\begin{array}{l}\mathrm{Vo}_{2} \\
{[\mathrm{~L} / \mathrm{min}]} \\
\text { średnie }\end{array}$ & $\begin{array}{c}\mathrm{Vo}_{2} \max ^{3} \\
{[\mathrm{~L} / \mathrm{min}]} \\
\text { średnie }\end{array}$ & $\begin{array}{c}\% \mathrm{Vo}_{2} \max ^{3} \\
\text { średnie }\end{array}$ & $\begin{array}{c}\mathrm{CO} \\
{[\mathrm{L} / \mathrm{min}]}\end{array}$ & $\begin{array}{c}\mathrm{CO}^{*} \\
{[\mathrm{~L} / \mathrm{min}]}\end{array}$ & $\begin{array}{c}\text { Różnica } \\
\text { procen- } \\
\text { towa }\end{array}$ & $\begin{array}{c}\mathrm{HR} \\
{[1 / \mathrm{min}]}\end{array}$ & $\begin{array}{c}\text { SV } \\
{[\mathrm{mL}]}\end{array}$ & $\begin{array}{l}\mathrm{SV}^{*} \\
{[\mathrm{~mL}]}\end{array}$ & $\begin{array}{c}\text { Różnica } \\
\text { procen- } \\
\text { towa }\end{array}$ \\
\hline 0,81 & 1,51 & 36,42 & 6,5 & 6,8 & 4,41 & 118,2 & 55,0 & 57,5 & 4,35 \\
\hline 1,85 & 1,51 & 57,62 & 8,5 & 8,7 & 2,29 & 155,5 & 54,7 & 55,9 & 2,15 \\
\hline 1,81 & 1,51 & 74,83 & 9,7 & 10,3 & 5,82 & 171,5 & 56,6 & 60,0 & 5,66 \\
\hline
\end{tabular}

$\mathrm{Vo}_{2} \mathrm{max}^{3}$ - maksymalne pochłanianie tlenu na bieżni ruchomej, $\% \mathrm{Vo}_{2}$ max $^{3}$ - wartość względnego obciążenia wysiłkiem fizycznym, CO - pojemność minutowa serca wyznaczona przez Turleya i Wilmore,

$\mathrm{CO}^{*}$ - pojemność minutowa serca wyznaczona własną metodą przez autorów pracy,

HR - częstość pracy serca,

SV - objętość wyrzutowa serca wyznaczona przez Turleya i Wilmore,

$\mathrm{SV}^{*}$ - objętość wyrzutowa serca wyznaczona własną metodą przez autorów pracy.

Źródło: Turley, Wilmore (1997); badania własne autorów.

Tabela 4. Dane morfometryczne chłopców w wieku od 7 do 9 lat badanych przez Turleyai Wilmore

\begin{tabular}{|c|c|c|c|c|c|c|}
\hline $\begin{array}{c}\text { Liczba } \\
\text { osób }\end{array}$ & $\begin{array}{c}\text { Wiek } \\
\text { [w latach] } \\
\text { średnie }\end{array}$ & $\begin{array}{c}\mathbf{m}[\mathbf{k g}] \\
\text { średnie }\end{array}$ & $\begin{array}{c}\mathbf{H}[\mathrm{m}] \\
\text { średnie }\end{array}$ & $\begin{array}{c}\mathbf{A}_{\mathrm{D}}\left[\mathrm{m}^{2}\right] \\
\text { średnie }\end{array}$ & $\begin{array}{c}\mathbf{V o}_{2} \mathbf{m a x}^{2} \\
{[\mathrm{~L} / \mathrm{min}]}\end{array}$ & $\begin{array}{c}\mathbf{V o}_{2} \mathbf{m a x}^{3} \\
{[\mathrm{~L} / \mathrm{min}]}\end{array}$ \\
\hline 12 & 9,1 & 29,5 & 1,34 & 1,04 & $1,49 \pm 0,20$ & $1,60 \pm 0,21$ \\
\hline
\end{tabular}

$\mathrm{m}$ - masa ciała,

$\mathrm{H}$ - wysokość ciała, 
$A_{D}-$ powierzchnia ciała,

$\mathrm{Vo}_{2} \max ^{2}-$ maksymalne pochłanianie tlenu na ergometrze rowerowym,

$\mathrm{Vo}_{2} \max ^{3}$ - maksymalne pochłanianie tlenu na bieżni ruchomej.

Źródło: Turley, Wilmore (1997).

Tabela 5. Wartości pojemności minutowej i objętości wyrzutowej serca przy różnych względnych obciążeniach wysiłkiem fizycznym chłopców na ergometrze rowerowym, wyznaczone przez Turleya i Wilmore oraz własną metodą przez autorów pracy

\begin{tabular}{|c|c|c|c|c|c|c|c|c|c|}
\hline $\begin{array}{c}\mathrm{Vo}_{2} \\
\text { [L/min] } \\
\text { średnie }\end{array}$ & \begin{tabular}{|l|}
$\mathrm{Vo}_{2} \max ^{2}$ \\
[L/min] \\
średnie \\
\end{tabular} & $\begin{array}{c}\% \mathrm{Vo}_{2} \max ^{2} \\
\text { średnie }\end{array}$ & $\begin{array}{c}\mathrm{CO} \\
{[\mathrm{L} / \mathrm{min}]}\end{array}$ & $\begin{array}{c}\mathrm{CO}^{*} \\
{[\mathrm{~L} / \mathrm{min}]}\end{array}$ & $\begin{array}{c}\text { Różnica } \\
\text { procen- } \\
\text { towa }\end{array}$ & $\begin{array}{c}\text { HR } \\
{[1 / \mathrm{min}]}\end{array}$ & $\begin{array}{c}\text { SV } \\
{[\mathrm{mL}]}\end{array}$ & $\begin{array}{l}\text { SV }^{*} \\
{[\mathrm{~mL}]}\end{array}$ & $\begin{array}{c}\text { Różnica } \\
\text { procen- } \\
\text { towa }\end{array}$ \\
\hline 0,55 & 1,49 & & & & 1 & & & & 4,36 \\
\hline 0,78 &, $4 S$ & & ৪, & & 6,02 & & 01 & $\pi, 4$ & 6,06 \\
\hline 1,02 & 1,49 & 68,48 & 9,4 & 9,1 & 3,19 & 153,1 & 61,4 & 59,4 & 3,26 \\
\hline
\end{tabular}

$\mathrm{Vo}_{2} \mathrm{max}^{2}$ - maksymalne pochłanianie tlenu na ergometrze rowerowym, $\% \mathrm{Vo}_{2} \mathrm{max}^{2}$ - wartość względnego obciążenia wysiłkiem fizycznym, CO - pojemność minutowa serca wyznaczona przez Turleya i Wilmore,

CO* - pojemność minutowa serca wyznaczona własną metodą przez autorów pracy,

HR - częstość pracy serca,

SV - objętość wyrzutowa serca wyznaczona przez Turleya i Wilmore,

$\mathrm{SV}^{*}$ - objętość wyrzutowa serca wyznaczona własną metodą przez autorów pracy.

Źródło: Turley, Wilmore (1997); badania własne autorów.

Tabela 6. Wartości pojemności minutowej i objętości wyrzutowej serca przy różnych względnych obciążeniach wysiłkiem fizycznym chłopców na bieżni ruchomej, wyznaczone przez Turleya i Wilmore oraz własną metodą przez autorów pracy

\begin{tabular}{|c|c|c|c|c|c|c|c|c|c|}
\hline \begin{tabular}{|c|}
$\mathrm{Vo}_{2}$ \\
[L/min] \\
średnie \\
\end{tabular} & $\begin{array}{l}\mathrm{Vo}_{2} \mathrm{max}^{3} \\
\text { [L/min] } \\
\text { średnie }\end{array}$ & $\begin{array}{c}\% \mathrm{Vo}_{2} \max ^{3} \\
\text { średnie }\end{array}$ & $\begin{array}{c}\mathrm{CO} \\
{[\mathrm{L} / \mathrm{min}]}\end{array}$ & $\begin{array}{c}\mathrm{CO}^{*} \\
{[\mathrm{~L} / \mathrm{min}]}\end{array}$ & $\begin{array}{c}\text { Różnica } \\
\text { procen- } \\
\text { towa }\end{array}$ & $\begin{array}{c}\mathrm{HR} \\
{[1 / \mathrm{min}]}\end{array}$ & $\begin{array}{c}\text { SV } \\
{[\mathrm{mL}]}\end{array}$ & $\begin{array}{l}\mathbf{S V}^{*} \\
{[\mathrm{~mL}]}\end{array}$ & $\begin{array}{c}\text { Różnica } \\
\text { procen- } \\
\text { towa }\end{array}$ \\
\hline 0,57 & 1,60 & & & & & & 57 & 50 & 156 \\
\hline 1,86 & $1,6 \mathrm{C}$ & & 8 , & 8, & 2,3 & & 60 & 58 & 2,33 \\
\hline 1,17 & 1,60 & 73,13 & 10,1 & 10,1 & & 168,3 & 60,0 & 60,0 & 0 \\
\hline
\end{tabular}

$\mathrm{Vo}_{2} \max ^{3}$ - maksymalne pochłanianie tlenu na bieżni ruchomej,

$\% \mathrm{Vo}_{2} \mathrm{max}^{3}$ - wartość względnego obciążenia wysiłkiem fizycznym,

$\mathrm{CO}$ - pojemność minutowa serca wyznaczona przez Turleya i Wilmore,

CO* - pojemność minutowa serca wyznaczona własną metodą przez autorów pracy,

HR - częstość pracy serca,

SV - objętość wyrzutowa serca wyznaczona przez Turleya i Wilmore,

$S V^{*}$ - objętość wyrzutowa serca wyznaczona własną metodą przez autorów pracy.

Źródło: Turley, Wilmore (1997); badania własne autorów. 


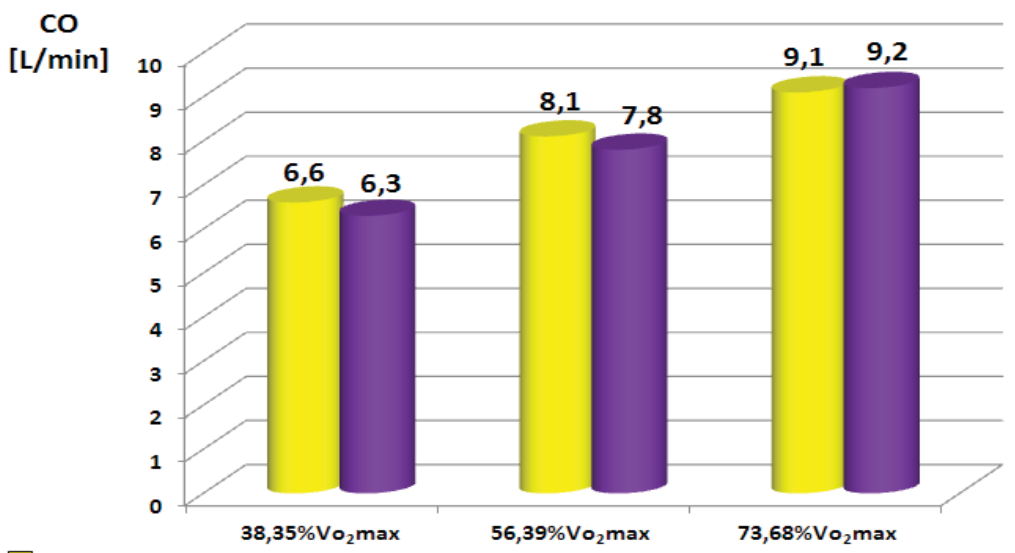

Wyniki otrzymane przez Turleya, Wilmore

Wyniki otrzymane przez autorów pracy

Rycina 1. Wartości pojemności minutowej serca $(\mathrm{CO})$ przy różnych względnych obciążeniach wysiłkiem fizycznym dziewcząt na ergometrze rowerowym, wyznaczone własną metodą oraz przez Turleya i Wilmore

Źródło: Turley, Wilmore (1997); badania własne autorów.

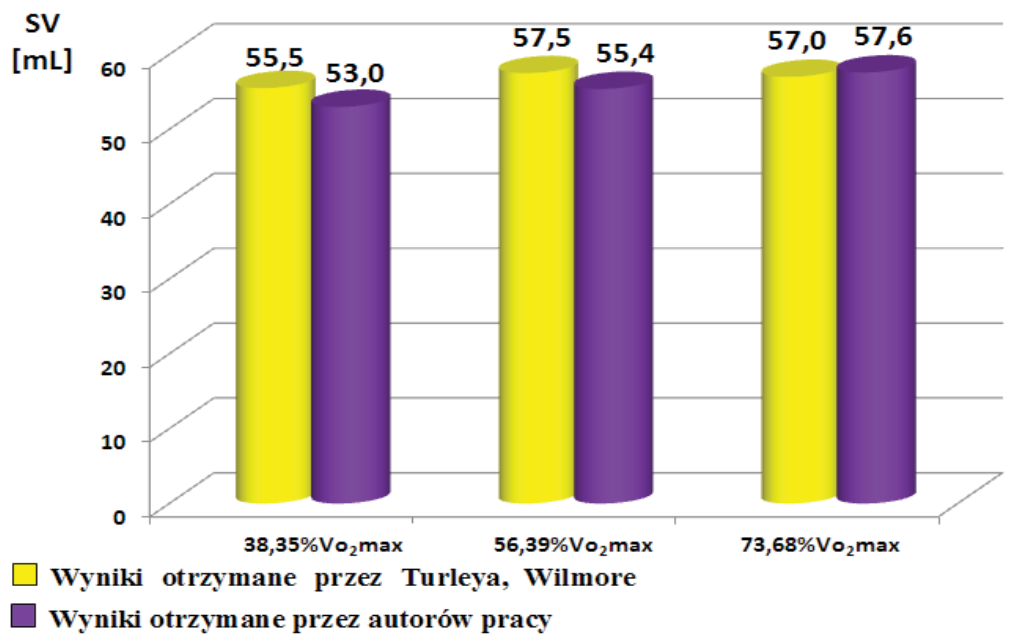

Rycina 2. Wartości objętości wyrzutowej serca (SV) przy różnych względnych obciążeniach wysiłkiem fizycznym dziewcząt na ergometrze rowerowym, wyznaczone własną metodą oraz przez Turleya i Wilmore

Źródło: Turley, Wilmore (1997); badania własne autorów. 
CO

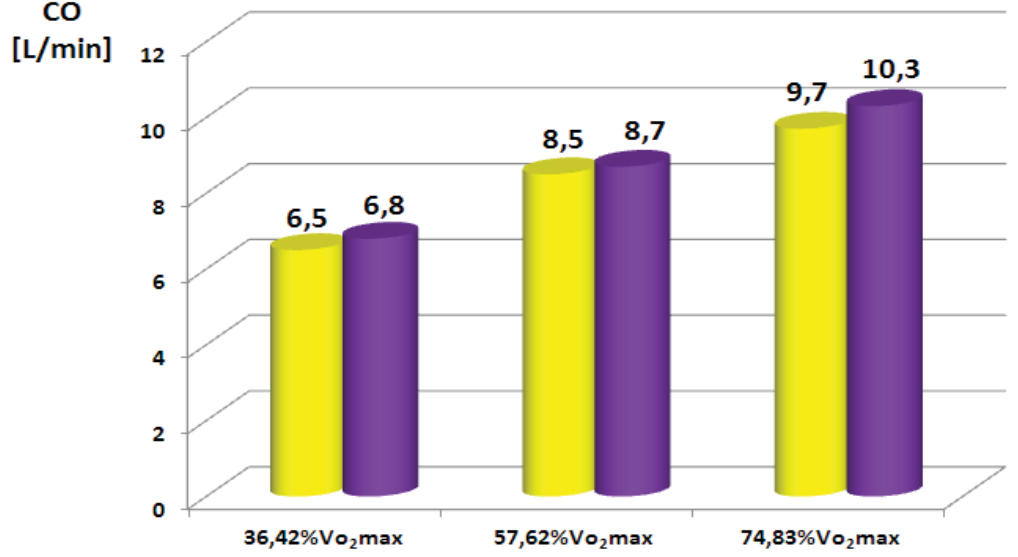

Wyniki otrzymane przez Turleya, Wilmore

Wyniki otrzymane przez autorów pracy

Rycina 3. Wartości pojemności minutowej serca $(\mathrm{CO})$ przy różnych względnych obciążeniach wysiłkiem fizycznym dziewcząt na bieżni ruchomej, wyznaczone własną metodą oraz przez Turleya i Wilmore

Źródło: Turley, Wilmore (1997); badania własne autorów.

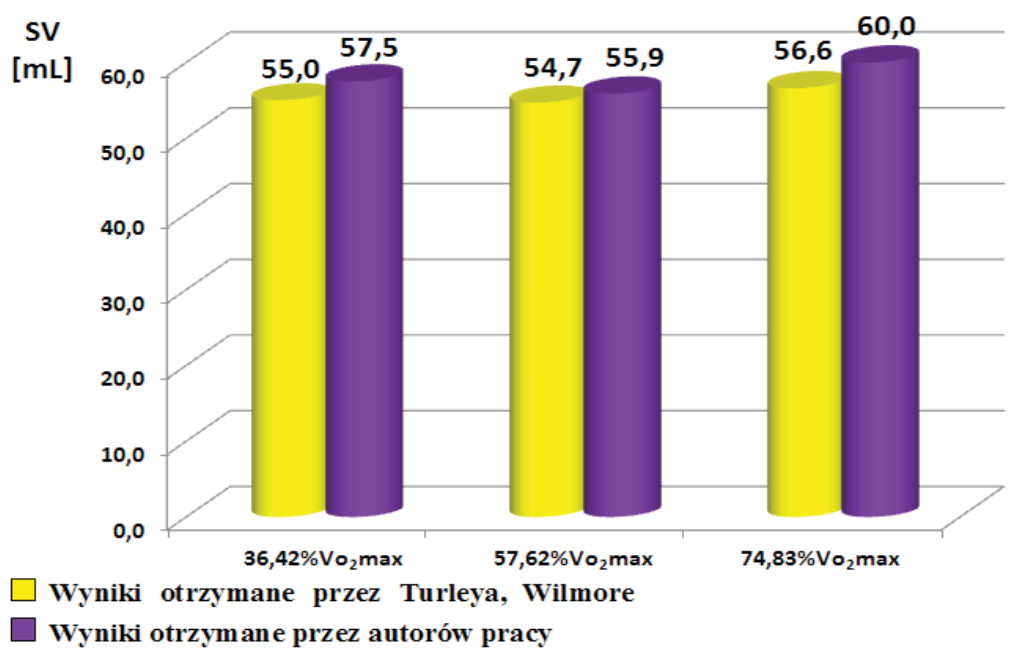

Rycina 4. Wartości objętości wyrzutowej serca (SV) przy różnych względnych obciążeniach wysiłkiem fizycznym dziewcząt na bieżni ruchomej, wyznaczone własną metodą oraz przez Turleya i Wilmore

Źródło: Turley, Wilmore (1997); badania własne autorów. 


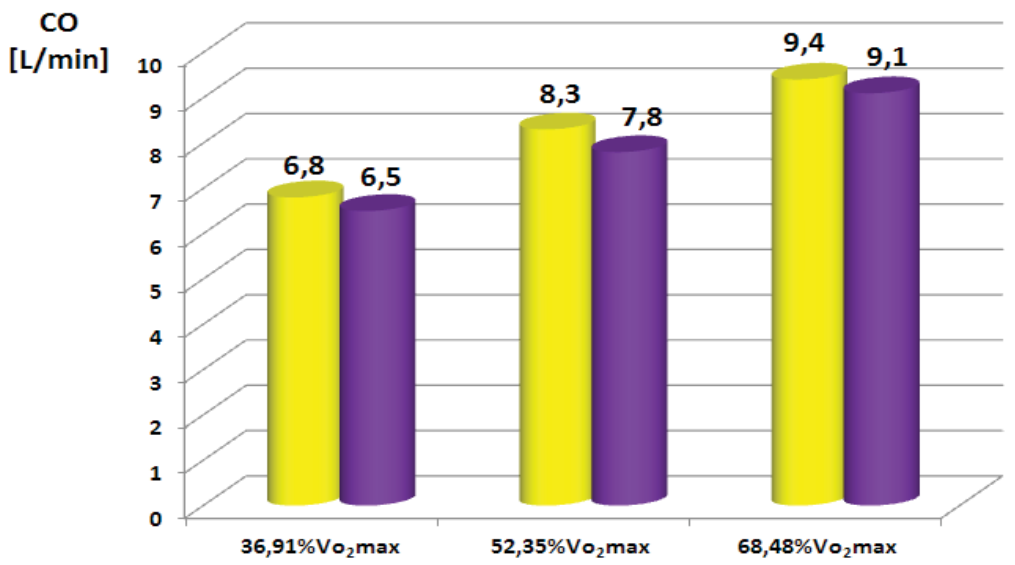

Wyniki otrzymane przez Turleya, Wilmore

Wyniki otrzymane przez autorów pracy

Rycina 5. Wartości pojemności minutowej serca (CO), przy różnych względnych obciążeniach wysiłkiem fizycznym chłopców na ergometrze rowerowym, wyznaczone własną metodą oraz przez Turleya i Wilmore

Źródło: Turley, Wilmore (1997); badania własne autorów.

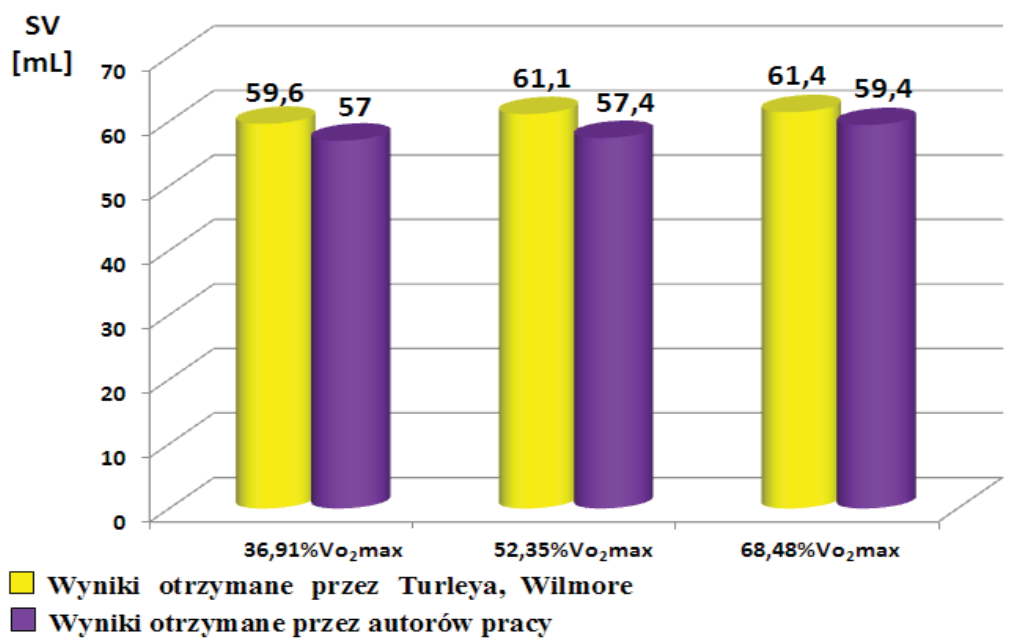

Rycina 6. Wartości objętości wyrzutowej serca (SV) przy różnych względnych obciążeniach wysiłkiem fizycznym chłopców na ergometrze rowerowym, wyznaczone własną metodą oraz przez Turleya i Wilmore

Źródło: Turley, Wilmore (1997); badania własne autorów. 
CO

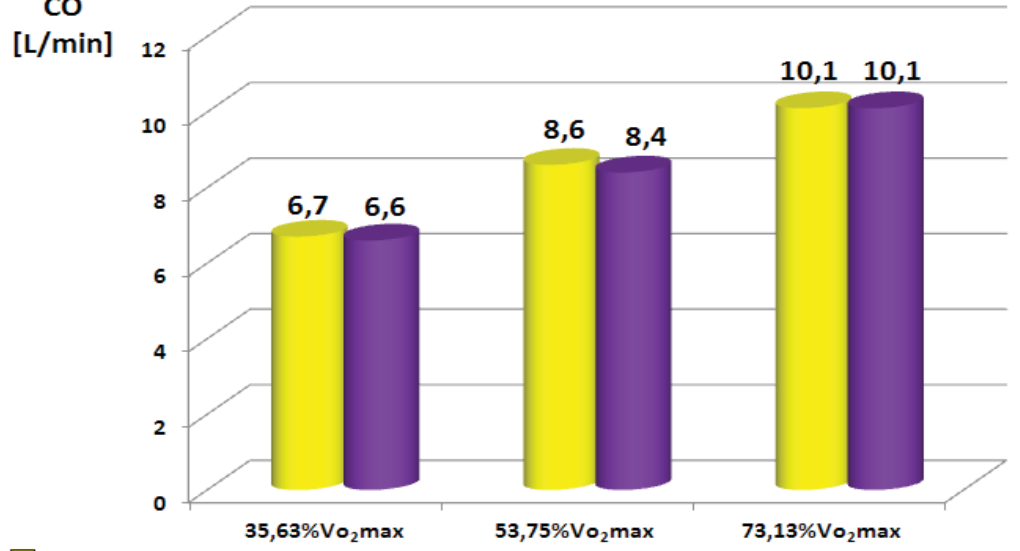

Wyniki otrzymane przez Turleya, Wilmore

Wyniki otrzymane przez autorów pracy

Rycina 7. Wartości pojemności minutowej serca (CO) przy różnych względnych obciążeniach wysiłkiem fizycznym chłopców na bieżni ruchomej, wyznaczone własną metodą oraz przez Turleya i Wilmore

Źródło: Turley, Wilmore (1997); badania własne autorów.

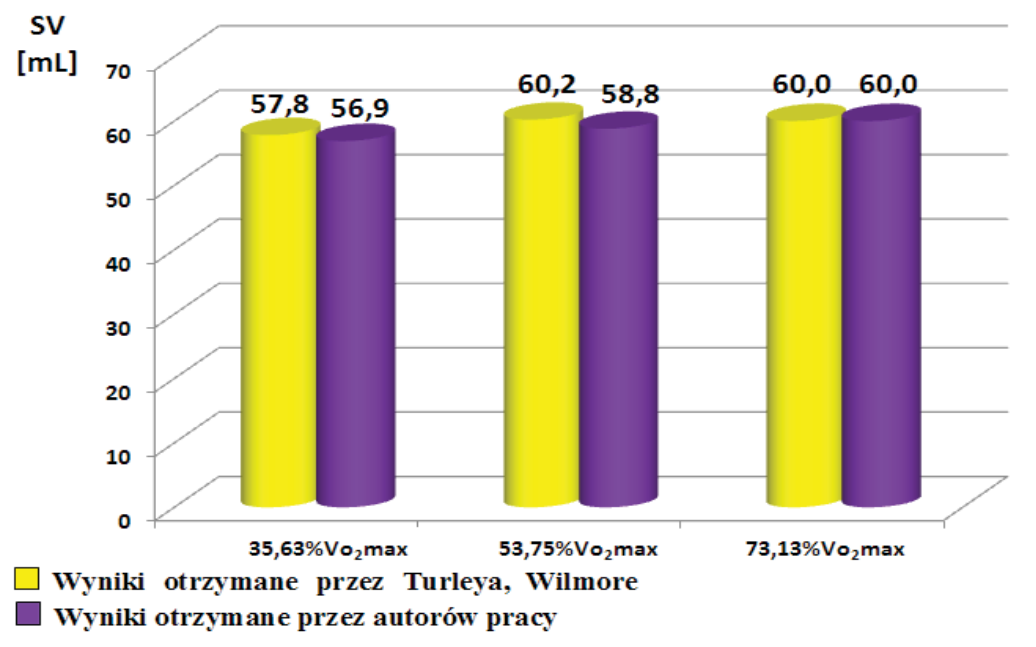

Rycina 8. Wartości objętości wyrzutowej serca (SV) przy różnych względnych obciążeniach wysiłkiem fizycznym chłopców na bieżni ruchomej, wyznaczone własną metodą oraz przez Turleya i Wilmore

Źródło: Turley, Wilmore (1997); badania własne autorów. 
Ocena statystyczna wykazała, że opracowane własne, nieinwazyjne metody wyznaczania CO i SV u dziewcząt i chłopców podczas różnego, względnego obciążenia wysiłkiem fizycznym dają wyniki nieróżniące się istotnie statystycznie od wyników otrzymanych u tych samych dzieci innymi metodami, przez innych badaczy.

Oznaczając wyniki CO otrzymane własną, nieinwazyjną metodą, literą X, a wyniki otrzymane u tych samych osób przez innych badaczy, innymi metodami, literą Y, wyznaczono współczynnik korelacji między wartościami X i Y: a) w przypadku dziewcząt $\left.r_{1}=0,979, b\right)$ w przypadku chłopców $r_{2}=0,993$.

\section{Podsumowanie}

Przedstawione wyżej wyniki badań oraz przeprowadzone badania statystyczne dowodzą, że własne, nieinwazyjne metody wyznaczania CO i SV dają wyniki nieróżniące się istotnie statystycznie od wyników otrzymanych innymi metodami, przez innych badaczy, u tych samych dziewcząt i chłopców.

Własne, nieinwazyjne metody pozwalają wyznaczyć CO i SV przy różnych względnych obciążeniach wysiłkiem fizycznym u dziewcząt i chłopców. Wykazano, że CO i SV zależą od względnego obciążenia wysiłkiem fizycznym $\left(\% \mathrm{Vo}_{2}\right.$ max), powierzchni ciała $\left(\mathrm{A}_{\mathrm{D}}\right)$, maksymalnego poboru tlenu $\left(\mathrm{Vo}_{2} \max \right)$ i częstości pracy serca (HR). CO jest funkcją potęgową (krzywoliniową), gdzie powierzchnia ciała jest w potędze 0,421 , zaś względne obciążenie wysiłkiem fizycznym jest w potędze 0,579 . Natomiast SV jest funkcją krzywoliniową rosnącą do 40-50\% względnego obciążenia wysiłkiem fizycznym. Dalsze zwiększanie względnego obciążenia powoduje zmniejszenie SV. Od tego momentu zwiększanie CO jest już wyłącznie skutkiem przyspieszenia częstości pracy serca. Opisany wyżej obraz zmian CO i SV w miarę zwiększania obciążenia względnego podczas wykonywania wysiłków w pozycji wyprostnej został przedstawiony na rycinach 9 i 10 i potwierdzony przez innych badaczy (Wilmore i in., 2008, Górski, 2008).

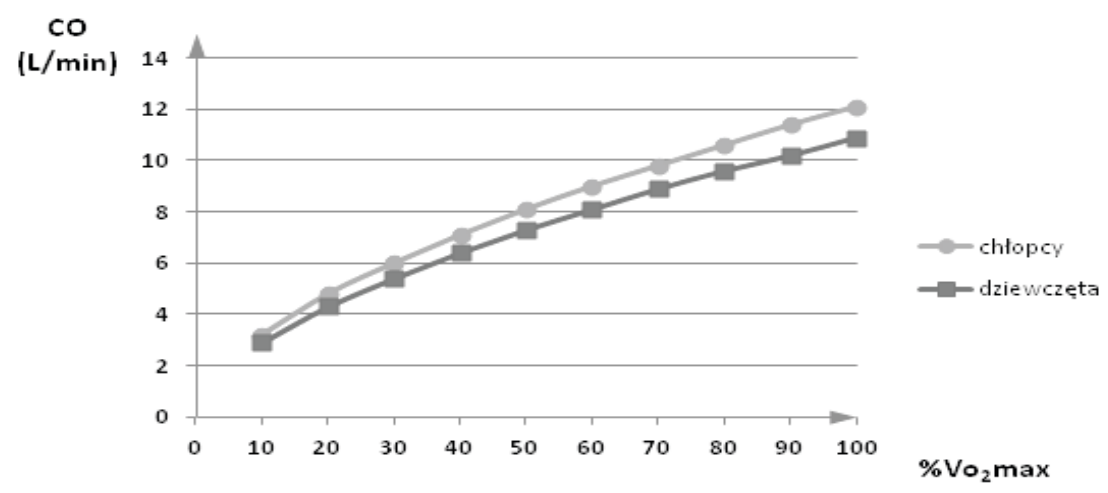

Rycina 9. Zmiany pojemności minutowej serca w funkcji względnego obciążenia wysiłkiem fizycznym u chłopców i dziewcząt, wyznaczone przez autorów pracy

Źródło: badania własne. 


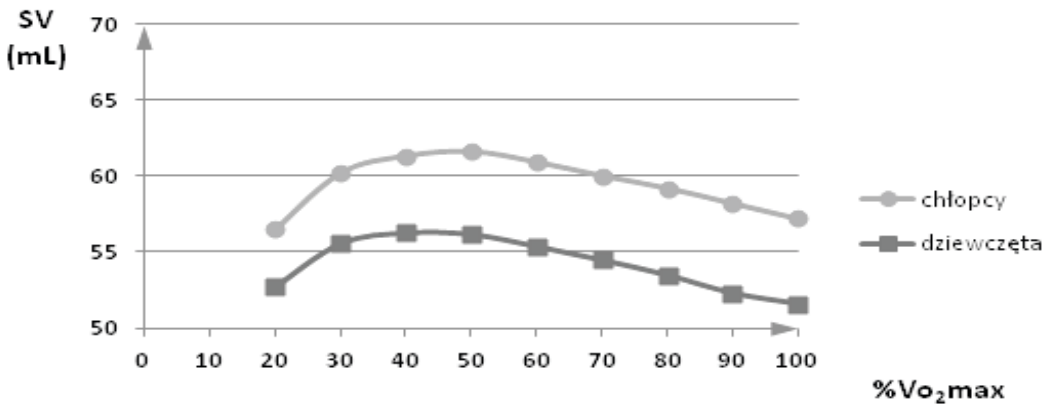

Rycina 10. Zmiany objętości wyrzutowej serca w funkcji względnego obciążenia wysiłkiem fizycznym u chłopców i dziewcząt, wyznaczone przez autorów pracy

Źródło: badania własne.

Opracowane metody wyznaczania CO i SV są metodami nieinwazyjnymi, pozwalającymi w prosty, tani, wiarygodny i bezpieczny sposób wyznaczyć te ważne parametry fizjologiczne podczas wysiłku fizycznego. Dotychczas w literaturze nie opisano podobnych metod. Opracowane własne metody mogą być alternatywne wobec stosowanych obecnie.

Metody inwazyjne: bezpośrednia i pośrednia metoda Ficka, metoda rozcieńczeń wskaźników cechują się koniecznością cewnikowania prawego lub lewego serca. Prawa komora cewnikowana jest zwykle z zastosowaniem cewnika Svan-Ganza z pływającym balonikiem, który po napełnieniu przemieszcza się z prądem krwi do gałęzi pnia tętnicy płucnej (Orłowski, 1988, Chlebus, Januszewicz, 1984, Rużyłło, Purzycki, 1984, Trafidło i in., 2010, Guzik i in., 2002, Branderburg, 1987, Peyton, Thompson, 2004, Ganz i in., 1971).

Metody inwazyjne są zazwyczaj czasochłonne i wymagają skomplikowanych technik pomiaru. Zmuszają do zaangażowania licznego wykwalifikowanego personelu i pochłaniają duże koszty związane z wartością sprzętu pomiarowego i cewników. Ponadto, zazwyczaj nie pozwalają na ciągłe monitorowanie parametrów hemodynamicznych (Guzik, 2002).

Metody o ograniczonej inwazyjności: angiografia radioizotopowa, cyfrowa angiografia subtrakcyjna (DSA) i tomografia komputerowa o wysokiej szybkości skanowania, wymagają podania pacjentowi środka cieniującego, cechuje je wysoki koszt, mała dostępność, narażenie badanego na promieniowanie jonizujące (Guyton, 1963, Orłowski, 1988, Chlebus, Januszewicz, 1984, Rużyło, Purzycki, 1984, Best, Taylor, 1971, Guzik i in., 2002).

Metody nieinwazyjne: rezonans magnetyczny cechuje się wysokimi kosztami, echokardiografia dwuwymiarowa (2 - D) i dopplerowska, które z kolei wymagają dużego doświadczenia od badającego i często cechują się małą dokładnością. Impedancję elektryczną klatki piersiowej cechuje niedokładność pomiarów u chorych z arytmią, wszczepionym stymulatorem po operacjach kardiochirurgicznych oraz z niedomykalnością zastawki aortalnej. Metoda oznaczania CO z użyciem gazu obcego obarczona jest niedokładnością pomiarów u chorych ze znaczącym 
przeciekiem płucnym oraz wymaga kosztownego aparatu (Guzik i in., 2002, Branderburg, 1987, Pepine, 1997, De Maria, Raisingham, 2000, Jarvis i in., 2007, Peyton, Thompson, 2004, Hirschl i in. 2000, Jansen i in., 1990, Strobeck, Silver, 2000, Raaijmakers i in., 1997, Wtorek, 2000, Laszlo, 2004).

Każda metoda ma swoje zalety i wady, które mogą ograniczyć jej stosowanie podczas badań. Do najczęstszych powikłań cewnikowania serca należy wstrząs lub hipotonia, migotanie komór, zatrzymanie czynności elektrycznej serca, częstokurcz napadowy i migotanie przedsionków, zawał, perforacja serca z tamponadą, odczyny infekcyjne i alergiczne, krwawienia i zmiany zakrzepowe w miejscu nakłucia naczyń, a także zatory tętnic mózgowych i obwodowych oraz tętnicy płucnej (Chlebus, Januszewicz, 1984, Jarvis i in., 2007, Patel i in., 1986).

Różnica wysycenia tlenowego między krwią tętniczą i żylną (AVD) jest wykładnikiem poboru tlenu w tkankach. Jak wynika $z$ równania Ficka $\left(\mathrm{CO}=\frac{\mathrm{O}_{2}}{\mathrm{AVD}}\right.$ $\left.\mathrm{CO}=\frac{\mathrm{O}_{2}}{\mathrm{AVD}}\right)$, wielkość ta jest odwrotnie proporcjonalna do pojemności minutowej (rzutu minutowego). W przypadku niewydolności krążenia, aby sprostać zwiększonemu zapotrzebowaniu na tlen, tkanki pobierają więcej tlenu, zwiększając w ten sposób różnicę tętniczo-żylną wysycenia krwi tlenem (AVD). Wyższe wartości AVD świadczą o niskim rzucie minutowym serca (CO) i mogą stanowić sygnał przemawiający za upośledzeniem czynności serca (Orłowski, 1988, Chlebus, Januszewicz, 1984, Rużyłło, Purzycki, 1984, Scheuer, Tipton, 1977).

Pomiar pojemności minutowej (rzutu minutowego) w czasie wysiłku jest ważnym wskaźnikiem stanu hemodynamicznego. Niski rzut minutowy w spoczynku, który nie zwiększa się istotnie w czasie wysiłku, może być wynikiem niedostatecznego wypełniania komory (np. zwężenia zastawki dwudzielnej, zwężenie zastawki trójdzielnej, zaciskające zapalenie osierdzia) lub niedostatecznego opróżniania komory (np. zwężenie zastawki aorty, zwężenie zastawki pnia płucnego, upośledzenie czynności kurczliwej samego mięśnia sercowego) (Orłowski, 1988, Chlebus, Januszewicz, 1984, Rużyło, Purzycki, 1984).

Nieprawidłowo wysoki rzut minutowy serca obserwuje się w stanach niepokoju, przy podwyższonej temperaturze ciała, nadczynności tarczycy, niedokrwistości, w chorobie beri-beri i przetokach tętniczo-żylnych (Wilmore i in., 2008, Kozłowski, Nazar, 1999, Mędraś, 2010, Klabunde, 2011, Orłowski, 1988, Chlebus, Januszewicz, 1984, Rużyłł, Purzycki, 1984).

Rzut minutowy serca zmniejsza się z wiekiem i jest mniejszy u kobiet niż mężczyzn; zmniejsza się przy zmianie pozycji leżącej na stojącą (Wilmore i in., 2008, Kozłowski, Nazar, 1999, Klabunde, 2011, Jaskólski, Jaskólska, 2006, Astrand i in., 2003).

Duży wzrost przepływu krwi w mięśniach, który zachodzi w czasie wysiłku fizycznego, jest skojarzony z podobnymi wzrostami pojemności minutowej serca, aż do sześciokrotnej wartości spoczynkowej oraz przez spadek przepływu krwi do mniej aktywnych tkanek, jak jelita, nerki i skóra, czyli zachodzi redystrybucja pojemności minutowej serca (Wilmore i in., 2008, Kozłowski, Nazar, 1999, Powers, Howley, 2009, Fox, 2008, Guyton, 1963, Keleman, 1977, Scheuer, Tipton, 1977).

Redystrybucja ukrwienia pozwala na osiągnięcie bardzo wysokiego ogólnego wychwytywania tlenu ze krwi - rzędu $85 \%$ w czasie intensywnego wysiłku. 
W czasie wysiłku do 70\% maksymalnej pojemności tlenowej, wzrost pojemności minutowej jest ogólnie proporcjonalny do poboru tlenu. Powyżej tego poziomu wzrost jest mniej proporcjonalny i występuje wzrastający metabolizm beztlenowy w mięśniach, z gromadzeniem się kwasu mlekowego we krwi obwodowej (Wilmore i in., 2008, Jaskólski, Jaskólska, 2006, Astrand i in., 2003, Guyton, Hall, 2005, Scheuer, Tipton, 1977).

Najłatwiejszym do zmierzenia i zarejestrowania wskaźnikiem reakcji układu krążenia na wysiłek jest wzrost częstości skurczów serca (HR). Zwiększenie HR następuje niemal natychmiast po rozpoczęciu wysiłku i po upływie 2-5 min stabilizuje się na poziomie odpowiadającym intensywności pracy (Wilmore i in., 2008, Kozłowski, Nazar, 1999, Powers, Howley, 2009, Fox, 2008, Klabunde, 2011, Clark i in., 1994). Maksymalna wartość $H R\left(\mathrm{HR}_{\max }\right)$ wykazuje niewielkie różnice międzyosobnicze i zmniejsza się wyraźnie z wiekiem. Przybliżona wartość $\mathrm{HR}_{\max }$ człowieka można obliczyć na podstawie wzoru: $\mathrm{HR}_{\max }=220$ - wiek (Wilmore $\mathrm{i}$ in., 2008, Kozłowski, Nazar, 1999, Jaskólski, Jaskólska, 2006, Astrand i in., 2003).

Gdy HR zostanie przedstawiony w funkcji względnego obciążenia wysiłkiem fizycznym (w \% Vo $\mathrm{o}_{2}$ max) wykazuje zależność liniową, która dla osób w tym samym wieku nie zależy od ich płci i poziomu wydolności fizycznej ( $\mathrm{V}_{2}$ max). Oznacza to, że HR przy tym samym obciążeniu względnym jest takie samo u sportowców i u ludzi prowadzących siedzący tryb życia (Wilmore i in. 2008, Kozłowski, Nazar, 1999, Powers, Howley, 2009, Keleman, 1977, Klabunde, 2011, Jaskólski, Jaskólska, 2006).

Maksymalna częstość pracy serca sportowców, tzn. osób o dużej wartości $V_{o_{2}} \max$, jest nieco mniejsza niż u osób o małej aktywności fizycznej (o małym $\mathrm{Vo}_{2} \max$ ). Sportowcy mają nie tylko niższą czynność serca w spoczynku, ale czynność serca wysiłkowa przy danym obciążeniu bezwzględnym, tzn. wyrażonym w watach, jest mniejsza niż u osób o małej aktywności fizycznej. Pojemność minutowa serca sportowców jest utrzymywana przez wyższe wartości objętości skurczowej (Wilmore i in., 2008, Kozłowski, Nazar, 1999, Powers, Howley, 2009, Górski, 2008, Fox, 2008, Keleman, 1977, Klabunde, 2011, Jaskólski, Jaskólska, 2006, Astrand i in., 2003, Guyton, Hall, 2005). Sportowcy mają wyższe objętości skurczowe nie tylko w czasie spoczynku, ale również podczas wysiłku o różnym natężeniu (Wilmore i in., 2008, Kozłowski, Nazar, 1999, Górski, 2008, Jaskólski, Jaskólska, 2006, Scheuer, Tipton, 1977).

Wszystkie dotychczas opracowane metody wyznaczania CO mają swoje ograniczenia i z tego powodu poszukuje się ciągle nowych możliwie prostych, tanich, bezpiecznych do zastosowania, ale wiarygodnych metod.

Opracowana przez autorów metoda wyznaczania CO i SV służy do nieinwazyjnego monitorowania układu krążenia podczas wysiłku fizycznego, jest wiarygodna i bezpieczna. Pozwala badać te ważne parametry hemodynamiczne u dziewcząt i chłopców w wieku 7-9 lat. 


\section{Wnioski}

1. Opracowana przez autorów metoda pozwala wyznaczyć CO i SV u dziewcząt i chłopców w wieku 7-9 lat.

2. Wartości CO i SV wyznaczone własną metodą i innymi metodami u tych samych dzieci, przez innych badaczy, nie wykazują istotnych różnic statystycznych.

3. Opracowana własna, nieinwazyjna metoda wyznaczania CO i SV jest prosta, tania i wiarygodna oraz nie powoduje zagrożenia zdrowia i życia osób badanych.

4. Opracowana własna metoda wyznaczania CO i SV może być alternatywną w stosunku do obecnie stosowanych metod wyznaczania tych parametrów hemodynamicznych podczas wysiłku fizycznego u dziewcząt i chłopców.

\section{Literatura}

Astrand P.O., Rodahl K., Dahl A.H., Stromme S.B., 2003, Textbook of work physiology, Human Kinetics, Champaign.

Balik M., Plasil P., Pazout J., Othal M., Frie M., Pachl J., 2004, Correlation of cardiac output measurement with transesophageal echocardiography and bolus thermodilution technique in patients with various of tricuspid regurgitation, Anest. Intenziv. Med., 15, s. 204-208.

Benson M.J., Cahalan M.K., 1995, Cost-benefit analysis of transesophageal echocardiography in cardiac surgery, Echocardiography, 12, s. 171-183.

Best C.H., Taylor N.B., 1971, Fizjologiczne podstawy postępowania lekarskiego, PZWL, Warszawa.

Branderburg R.O., 1987, Cardiology: Fundamentals and Practice, Year Book Medical Publishers, Inc. Chicago.

Braunwald E., 1998, Heart Disease. A textbook of cardiovascular medicine, W.B. Saunders Company, Philadelphia.

Bródka J., Tułecki Ł., Ciurysek M., Gburek T., 2010, Porównanie rzutu minutowego serca mierzonego metodą termodylucji i echokardiografii przezprzełykowej u chorych z dobrą czynnością skurczową lewej komory, Anestezjologia Intensywna Terapia, 17(1), s. 15-18.

Bukowski J., 1976, Mechanika płynów, PWN, Warszawa.

Chlebus H., Januszewicz W., 1984, Zarys kardiologii, PZWL, Warszawa.

Clark S.L., Southwick J., Pivarnik J.M., 1994, A comparison of cardiac index in normal term pregnancy using thoracic electrical bio-impedance and oxygen extraction (Fick) techniques, Obstet. Gynecol., 83, s. 669-672.

Darmon P.L., Hillel Z., Mogtader A., Mindich B., Thys D.M., 1994, Cardiac output by transesophageal echocardiography using continuous-wave Doppler across the aortic valve, Anesthesiology, 80 , s. $796-805$.

Della Rocca G., Costa M.G., Pompei L., Coccia C., Pietropaoli P., 2002, Continuous and intermittent cardiac output measurement pulmonary artery catheter versus aortic transpulmonary technique, Br. J. Anaesth., 88, s. 350-356.

De Maria A.N., Raisingham A., 2000, Comparative overview of cardiac output measurement methods: has impedance cardiography come of age? Congestive Heart Failure, 6, s. 7-18.

Feinberg M.S., Hopkins W.E., Davila-Roman V.G., Barzilai B., 1995, Multiplane transesophageal echocardiographic Doppler imaging accurately determines cardiac output measurements in critically ill patients. Chest, 107, s. 796-773.

Fox S., 2008, Human physiology, Mc Graw-Hill, Campanies, New York. 
Ganz W., Donoso R., Marcus H.S., Forrester J.S., Swan H.J.C., 1971, A new technique for measurement of cardiac output by thermodilution in men, Am. J. Cardiol., 27, s. 392-396.

Gödje O., Höke K., Goetz A.E., Felbinger T.W., Reuter D.A., Reichart B. et al., 2002, Reliability of a new algorithm for continuous cardiac output determination by pulse-contour analysis during hemodynamic intability, Crit. Care Med., 30, s. 52-58.

Górski J., 2008, Fizjologiczne podstawy wysiłku fizycznego, PZWL, Warszawa.

Guyton A.C., 1963, Cardiac output end its regulation, W.B. Saunders Company, Philadelphia.

Guyton A., Hall J., 2005, Textbook of medical physiology, W.B. Saunders, Philadelphia.

Guzik P., Greberski K., Wysocki H., 2002, Porównanie inwazyjnych i nieinwazyjnych metod pomiaru parametrów hemodynamicznych, Nowiny Lek., 71(6), s. 349-354.

Haniszewski B., 1980, Wymiana ciepła, PWN, Warszawa.

Hirschl M.M., Kitler H., Woisetschlager C., 2000, Simultaneous comparison of thoracic bioimpedance and arterial pulse waveform-derived cardiac output with thermodilution measurement, Crit. Care Med., 28, s. 1798-1802.

Hobler T., 1979, Ruch ciepła i wymienniki, WNT, Warszawa.

Jansen J.R.C., Wesseling K.H., Settels J.J., 1990, Continuous cardiac output monitoring by pulse contour during cardiac surgery, Eur. Heart J., 11, s. 26-32.

Jarvis S.S., Levine B.D., Prisk G.K., Shykoff B.E., Elliott A.R., Rosow E., Blomquist C.G., Pawelczyk J.A., 2007, Simultaneous determination of the accuracy and precision of closed-circuit cardiac output rebreathing techniques, J. Appl. Physiol., 103(3), s. 867-874.

Jaskólski A., Jaskólska A., 2006, Podstawy fizjologii wysitku fizycznego, AWF, Wrocław.

Keener J., Sneyd J., 1998, Mathematical physiology, Springer-Verlag, New York.

Keleman G.R., 1977, Applied cardiovascular physiology, Butterworths, London-Boston-Sydney.

Klabunde R.E., 2011, Cardiovascular physiology concepts, Lippincott Williams \& Wilkins, Philadelphia.

Kozłowski S., Nazar K., 1999, Wprowadzenie do fizjologii klinicznej, PZWL, Warszawa.

Kucewicz E., Czech B., Juszczyk G., Jackowski R., Szapiel G., Bartosiewicz I., Siemiątkowski A., 2003, Ocena porównawcza dwóch metod śródoperacyjnego pomiaru rzutu minutowego serca (termodilucja $i$ echokardiografia przezprzełykowa) u chorych poddawanych zabiegom pomostowania tętnic wieńcowych z użyciem krążenia pozaustrojowego, Anestezjologia Intensywna Terapia, 10(1), s. 3-7.

Kurita T., Morita K., Kato S., Kikura M., Horie M., Ikeda K., 1997, Comparison of the accuracy of the lithium dilution technique with the thermodilution technique for measurement of cardiac output, Br. J. Anaesth., 79, s. 770-775.

Landau L., Lifszic E., 1958, Mechanika ośrodków ciągłych, PWN, Warszawa.

Laszlo G., 2004, Respiratory measurements of cardiac output: from elegant idea to useful test, J. Appl. Physiol., 96, s. 428-437.

Liu Y., Menold E., Dullenkopf A., Reissnecker S., Lormes W., Lehmann M., Steinacker J.M., 1997, Validation of the acetylene rebreathing method for measurement of cardiac output at rest and during high-intensity exercise, Clin. Physiol., 17, s. 171-182.

Matthews G.G., 2000, Neurobiologia, PZWL, Warszawa.

Mayer J., Boldt J., Schollhorn T., Rohm K.D., Mengistu A.M., Suttner S., 2007, Semi-invasive monitoring of cardiac output by a new device using arterial pressure waveform analysis: a comparison with intermittent pulmonary artery thermodilution in patients undergoing cardiac surgery, $\mathrm{Br}$ J. Anaesth, 98, s. 176-182.

Mędraś M., 2010, Endokrynologia wysiłku fizycznego sportowców, Medpharm, Wrocław.

Nielsen O.W., Hansen S., Christensen P., Granlund J., 1990, Repeatability of the acetylene rebreathing method in measuring cardiac output: influence of acetylene concentration. Acta Anaesthesiol. Scand., 34, s. 354-357.

Nilsson L.B., Eldrup N., Berthelsen P.G., 2001, Lack of agreement between thermodilution and carbon dioxide-rebreathing cardiac output. Acta Anaesthesiol. Seand., 45, s. 680-685.

Olszowska A.J., Shykoff B.E., Pendergast D.R., Farhi L.E., 2004, Revised one-step method for determination of cardiac output. Respir. Physiol. Neurobiol., 140, s. 99-109.

Orłowski W., 1988, Nauka o chorobach wewnętrznych, tom I: Choroby układy krążenia, PZWL, Warszawa. 
Patel C., Laboy V., Venus B., Mathru M., Wier D., 1986, Acute complications of pulmonary artery eatheter insertion in critically ill patients. Crit. Care Med., 14, s. 195-197.

Pepine C.J., 1997, Diagnostic and therapeutic cardiac catheterization, Williams \& Wilkins A Waverly Company, Baltimore.

Peyton P.J., Thompson B., 2004, Agreement of an inert gas rebreathing device with thermodilution and the direct oxygen Fick method in measurement of pulmonary blood flow, J. Clin. Monit. Comput., 18, s. 373-378.

Powers S.K., Howley E.T., 2009, Exercise physiology, Mac Graw-Hill, Boston.

Raaijmakers E., Faes Th.J.C., Goovaerts H.G., de Vries P.M.J.M., Heethaar R.M., 1997, The inaccuracy of Kubicek's one-cylinder model in thoracic impendance cardiography, IEEE Trans. Biomed. Eng., 44, s. 70-76.

Rużyłło W., Purzycki Z., 1984, Diagnostyka hemodynamiczna serca, PZWL, Warszawa.

Scheuer J., Tipton Ch.M., 1977, Cardiovascular adaptations to physical training, Ann Rev. Physiol., 39 , s. $221-251$.

Sherwood A., McFetridge J., Huthenson J.S., 1998, Abulatory impendance cardiography: a feasibility study, J. Appl. Physiol., 85, s. 2365-2369.

Shoemaker W.C., Wo C.C.J., Bishop M.H., 1994, Multicanter trial of a new thoracic electrical bioimpendance device for cardiac output estimation, Crit. Cave Med., 22, s. 1907-1912.

Strobeck J.E., Silver M.A., Ventura H., 2000, Impendance cardiography: noninvasive measurement of cardiac stroke volume and thoracic fluid content, Congestive Heart Failure, 6, s. 3-6.

Swanevelder J., 2001, The role of transoesophageal echocardiography for the cardiac anaesthetist, Anestezjologia Intensywna Terapia, 33 (Suppl.), s. 10-13.

Szubert J., 1980, Biofizyczne aspekty termoregulacji w organizmie człowieka, WAM, Łódź.

Szubert J., 1981, Modelowanie i symulacja komputerowa jako metody badan we współczesnej biologii i medycynie, Pol. Tyg. Lek., 36(25), s. 943-946.

Trafidło T., Gaszyński T., Gaszyński W., 2010, Monitorowanie pojemności minutowej serca metodami mniej inwazyjnymi, Anestezjologia i Ratownictwo, 4, s. 99-110.

Turley K.R., Wilmore J.H., 1997, Cardiovascular responses to treadmill and cycle ergometer exercise in children and adults, J. Appl. Physiol., 83(3), s. 948-957.

Wiesenack C., Prasser C., Keyl C., Rodig G., 2001, Assessment of intrathoracic blood volume as an indicator of cardiac preload: single transpulmonary thermodilution technique versus assessment of pressure preload parameters derived from a pulmonary artery catheter, $\mathrm{J}$ Cardiothorac. Vasc. Anesth., 15, s. 584-588.

Wilmore J.H., Costill D.L., Kenney W.L., 2008, Physiology of sport and exercise, Human Kinetics, Champaign.

Wright R.F., Gilbert J., 2000, Clinical decision making in patients with congestive heart failure: the role of thoracic electrical bioimpendance, Congestive Heart Failure, 6, s. 27-31.

Wtorek J., 2000, Relations between components of impendance cardiogram analysed by means of finite element model and sensitivity theorem, Ann. Biomed. Eng., 28(11), s. 1352-1361.

Zeidifard E., Davis C.T., 1978, Anassessment of a $\mathrm{N}_{2} \mathrm{O}$ rebreathing method for the estimation of cardiac output during severe exercise, Ergonomics, 21, s. 567-572. 